Journal of Current and Advance Medical Research

July 2017, Vol. 4, No. 2, pp. 34-35

http://www.banglajol.info/index.php/JCAMR

ISSN (Print) 2313-447X

ISSN (Online) 2413-323X

DOI: http://dx.doi.org/10.3329/jcamr.v4i2.36351

\title{
EDITORIAL
}

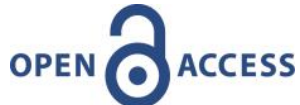

\section{Patient Empowerment: A New dimension in Gestational Diabetes Mellitus Management?}

\author{
Fatema Ashraf ${ }^{1}$, M. Tasdik Hasan ${ }^{2}$
}

\begin{abstract}
${ }^{1}$ Professor \& Head, Department of Obstetrics \& Gynecology, Shaheed Suhrawardy Medical College, Sher-E-Bangla Nagar, Dhaka, Bangladesh; ${ }^{2}$ Research Investigator, International Center for Diarrhoeal Diseases Research, Bangladesh
\end{abstract}

Gestational diabetes mellitus (GDM) is a rising threat to public health ${ }^{1}$. It has accounted for $85.1 \%$ of 20.9 million live births caused by hyperglycemia globally only in $2015^{2}$. In Bangladesh the prevalence is ranging from $6 \%$ to $14 \%$ as per different diagnostic methods ${ }^{3}$. Uncontrolled GDM often leads to maternal and foetal morbidities and mortalities which can be worst in in underprivileged society. The maternal morbidities are prolonged labour, obstructed labour and increased rate of caesarean section and maternal infections which may develop type 2 diabetes mellitus subsequently ${ }^{4}$. Babies can also suffer from macrosomia, foetal distress, birth injuries, birth asphyxia, neonatal hypoglycemia, neonatal death and development of type 2 diabetes mellitus in early adult life ${ }^{4}$.

Keeping blood sugar level within a normal range in day to day life is the main stay of GDM management ${ }^{2}$. However in any form, the management includes measured diet, life style modification, drugs and on the top maintaining discipline. Therefore, diabetes management model during pregnancy should involve the patient in every steps of management to make it a successful one.

Our thought was to design \& implement the 'Patient empowerment' model to manage diabetes during pregnancy. For empowerment, the patient should have a clear understanding about the disease, its pathogenesis and both short \& long term consequences of mother and the baby. Furthermore, the patient needs to assess and interpret her own blood sugar. Simple health education in one sitting may not work worthy, rather continuous learning, training and monitoring of patients performances through multiple successive sessions can give a better outcome. Thus a patient empowerment model was developed and applied to find out its efficacy for GDM management at a selected Tertiary level Public hospital ${ }^{5}$. A control group was recruited from similar tertiary level public hospital. Result showed lower rate of maternal infections, higher rate of vaginal birth (66.7\% vs $33.3 \%)$ and low use of Inj. Insulin $(25.0 \%$ vs $75.0 \%)$ in intervention group in comparison to control group.

Patient's training on diet calculation and diet exchange was based on daily calorie requirement and blood sugar level interpretation. It was followed by redistribution of diet in appropriate meal, matched with food supply is the core of dietary management so each patient need to be admitted for at least 3 to 4 days. It seems quite impractical for a large scale study to admit the patient for health education and to empower them at the end of hospital management in a developing country setting. In this context, the investigators are now considering apps to overcome the challenges. Group of experts from the Ministry of ICT are working on this issue and are using the artificial intelligence (AI) based software which may be an effective tool for management of GDM cases. If it is a successful one a new dimension in the management of GDM will be achieved in this century.

\section{References}

1. Mahtab H and Bhowmik B. Gestational Diabetes Mellitus - Global and Bangladesh Perspectives. Austin J Endocrinol Diabetes. 2016; 3(2): 1041

2. International Diabetes Federation. Diabetes Atlas. $7^{\text {th }}$ edition. 2015

3. Jesmin S, Akter S, Akashi H, Al-Mamun A, Rahman MA, Islam MM, et al. Screening for gestational diabetes mellitus and its prevalence in Bangladesh. Diabetes Res Clin Pract. 2014; 103: 57-62 
4. Jesmin S, Jahan S, Khan MI, N Sultana, J Jerin, SH Habib, et al. The incidence, Predisposing Factors, Complication and Outcomes of Preeclamsia in Diabetes Pregnancy. Birdem Med J. 2011; 1: 10-14

5. Unpublished Manuscript by Professor Fatema Ashraf et al (2017), Study paper was presented at $12^{\text {th }}$ SEA Regional conference of Epidemiologists at Thailand

[Journal of Current and Advance Medical Research 2017;4(2):34-35]
Correspondence: Dr. Fatema Ashraf, Professor \& Head, Department of Obstetrics \& Gynecology, Shaheed Suhrawardy Medical College, Sher-E-Bangla Nagar, Dhaka, Bangladesh; Email: fatema.phfbd@gmail.com; Cell no.: +880 1711-855941

Cite this article as: Ashraf F, Hasan MT. Patient Empowerment: A New dimension in Gestational Diabetes Mellitus Management? J Curr Adv Med Res 2017;4(2):34-35 